\title{
ADAPTATION TO THE INFORMATION SOCIETY OF PEOPLE WITH DISABILITIES IN SLOVAKIA
}

\section{Anna Ondrejková ${ }^{1}$}

\begin{abstract}
The information and communication technology (ICT) is an important phenomenon of contemporary society, in particular in developed countries. The massive use of ICT has created an information society. Changes caused by the increasing importance of information and ICT are not only technological or economic, but are social, directly affecting the lives of citizens. The ICT usage offers a great opportunity for people with disabilities. Important factors for enhancing quality of life for this part of the population include mapping the current state and the increasing level of digital literacy. The aim of this paper is to view digital literacy in the context of social and digital integration for people with disabilities in the society of the Slovak Republic and especially present results of social research in digital literacy of this minority in Slovakia. The study involves a quantitative type of social research. The techniques of data collection for the research included an electronic questionnaire form. The technology for developing the questionnaire involved Google forms. The results of this research show how people with disabilities could adapt to the information society.
\end{abstract}

JEL Classification Numbers: O330, J24, DOI: http://dx.doi.org/10.12955/cbup.v4.767

UDC Classification: 308

Keywords: digital literacy, the information and communication technology, people with disabilities.

\section{Introduction}

Digital literacy has become one of the core competencies of the 21 st century. The chances to obtain a better position on the labor market are minimal without the ability to effectively and responsibly use digital media and ICT. Although the use of ICT and the global worldwide Internet is highly topical and widespread, there is still a segment of the population that have no access to the latest technologies, or cannot effectively use modern technology, and possibly cannot extract the most from new technologies.

Today, every citizen needs to be able to use modern ICT effectively in present day situations. This is crucial, not only young people and the general population, but also people of the 'third age' and the people with disabilities.

To better digitally equip seniors or people with disabilities, their goals for the digital usage need consideration, including the areas in which digital activity is socially meaningful and contributes directly to the development of the people and their integration into modern society.

The contemporary society is a knowledge society or sometimes known as a knowledge-based society. A knowledge society is characterized by "mass access and use of information and knowledge, stored and processed by information technology accordance user requirements" (Kelemen et al, 2007, p. 15). One of its symptoms is the significant change in the economy caused by an increased status of knowledge in producing to its other elements.

The knowledge economy focuses on products and services containing processed knowledge, 'intelligence', and favors professionals concerned with their development. The world community achieved this knowledge level only in a minority of countries. In Slovakia, the important factor of production is manual labor. Accordingly, Slovakian's can speak about the knowledge society only as a target (Lipovská, Hvorecký, \& Šimúth, 2014, p. 18).

The Slovak society is located in a phase of being 'in front of a knowledge', with a focus on traditional resources for economic production. Worldwide, "society has experienced a similar historic leap in

\footnotetext{
${ }^{1}$ Anna Ondrejková, University of Economics in Bratislava, Faculty of Economic Informatics, Dolnozemská cesta 1/b, 852 35 Bratislava, Slovak Republic, ondrejka@euba.sk
} 
economic development, which was the industrial revolution in the 18th and 19th centuries. A change can be observed also today. The people with little education looking for a job find it increasingly difficult “(Lipovská, Hvorecký, \& Šimúth, 2014, p. 19).

This strengthens the position of workers who perform activities that are difficult to automate. Jobs, in which knowledge workers operate, as a rule, require higher education. As a result, the role of education is growing in the knowledge society (Lipovská, Hvorecký, \& Šimúth, 2014, p. 19).

Economic globalization and a knowledge-based society accompany changes in core competencies. The three core competencies (reading, writing, and arithmetic) correspond to the mass model of education in industrial society. Currently, digital literacy is one of these key competences.

Digital literacy, in general, includes the ability to understand information and use such in a variety of formats using modern ICT though different sources. The readiness of the population to use modern ICT is a key precondition for successful transformation in the information society and the knowledgebased economy.

As the author previously wrote:

In the last two decades, the issue of people with disabilities is extremely current and supported by the strategic objectives and documents of the European Union and developed countries of the world, how it declared one of the most important documents of the United Nations on these issues - the UN Convention on the Rights of Persons with Disabilities and the Optional Protocol, which was approved by the United Nations on 13 December 2006 and to which the EU is a party. This paper showcases the position regarding the level of digital integration for people with disabilities in the society of the Slovak Republic. To enhance the quality of life for this part of the population, increasing the level of digital literacy is an important factor. (Ondrejková, 2015, p. 201).

Then, there is:

For many people with disabilities we can mark ICT as new opportunity for increasing the quality of their lives. New technology and especially the Internet, as a global means of communication, allows disabled people to keep in touch with the surroundings, electronically communicate with anyone, use the online electronic services within the framework of inclusive e-Government. The people with disabilities can use of telework options in the future, apply their own abilities, expand your education, to take advantage of the progressive form of e-learning. The transition of society to the information society is bringing problems associated with deepening social inequality, which is showed itself as the "digital divide". The application of modern ICT in itself carries the risk of digital exclusion from society (Ondrejková, 2015. p. 200).

The aim of this paper is to emphasize the importance of the digital agenda, and the need for faster development in Slovakia in specific areas. We focus on the field of digital skills and digital literacy as an essential prerequisite for digitization of society, especially to the adaptation of people with disabilities to these challenges, and the assumptions of integration in contemporary society with a growing trend of using dynamically evolving ICT in everyday life.

\section{Digital Economy and Society Index (DESI) - Measurement Tool of Digital Readiness of the EU Countries}

The European Commission promoted the use of ICT for European Union countries in the Europe 2020 strategy, especially as a 'Digital Agenda' for Europe. The Digital Agenda proposes to better exploit the potential of ICT to promote innovation, economic growth, and progress (Europe 2020 strategy, 2016). In 2015, the European Commission introduced a new analytical tool, the Digital Economy and Society Index (DESI) for assessing the readiness of the European Union countries in terms of the Digital Agenda.

This new tool aims to measure the following five areas of digitization: connectivity, human capital, use of the Internet, the integration of digital technologies, and digital public services (Kosno, 2016). 
Slovakia's position in terms of the DESI index in 2016 was not satisfactory. Among the 28 member states, Slovakia was rated number 21, with several sectors placed around the EU average.

The number of regular Internet users is increasing, basic digital skills are improving, and the country has a decent share of ICT specialists. Slovakia total score was 0.46 and was number 21 out of $28 \mathrm{EU}$ Member States. Slovaks have a high level of digital skills (74\% regularly use the Internet, 53\% have at least a basic digital skills). This reflects Slovaks being highly active online with $65 \%$ reading news online, $69 \%$ using social networks, and 55\% using voice or video calls over the Internet. However, progress is needed in terms of Internet access.

For example, $14 \%$ of Slovak households do not have a fixed broadband connection. However, there is considerable potential for better integration of digital technologies businesses compared with other EU countries (What is the digital readiness of Slovakia, 2016).

Furthermore, Slovakia needs to significantly improve the complexity of digital public services to promote the digital economy and society in Slovakia (Kosno, 2016).

Based on the DESI, the Commission divided the Member States into four groups in 2016. Slovakia had achieved a lower overall indicator than the EU average, and in addition, the growth rate was lower than average. The Group of Eight countries with similar data was shown by the European Commission as lagging behind (group of 'falling behind'). Half of the countries indicated constitutes the Visegrad Group (Šimkovič, 2016).

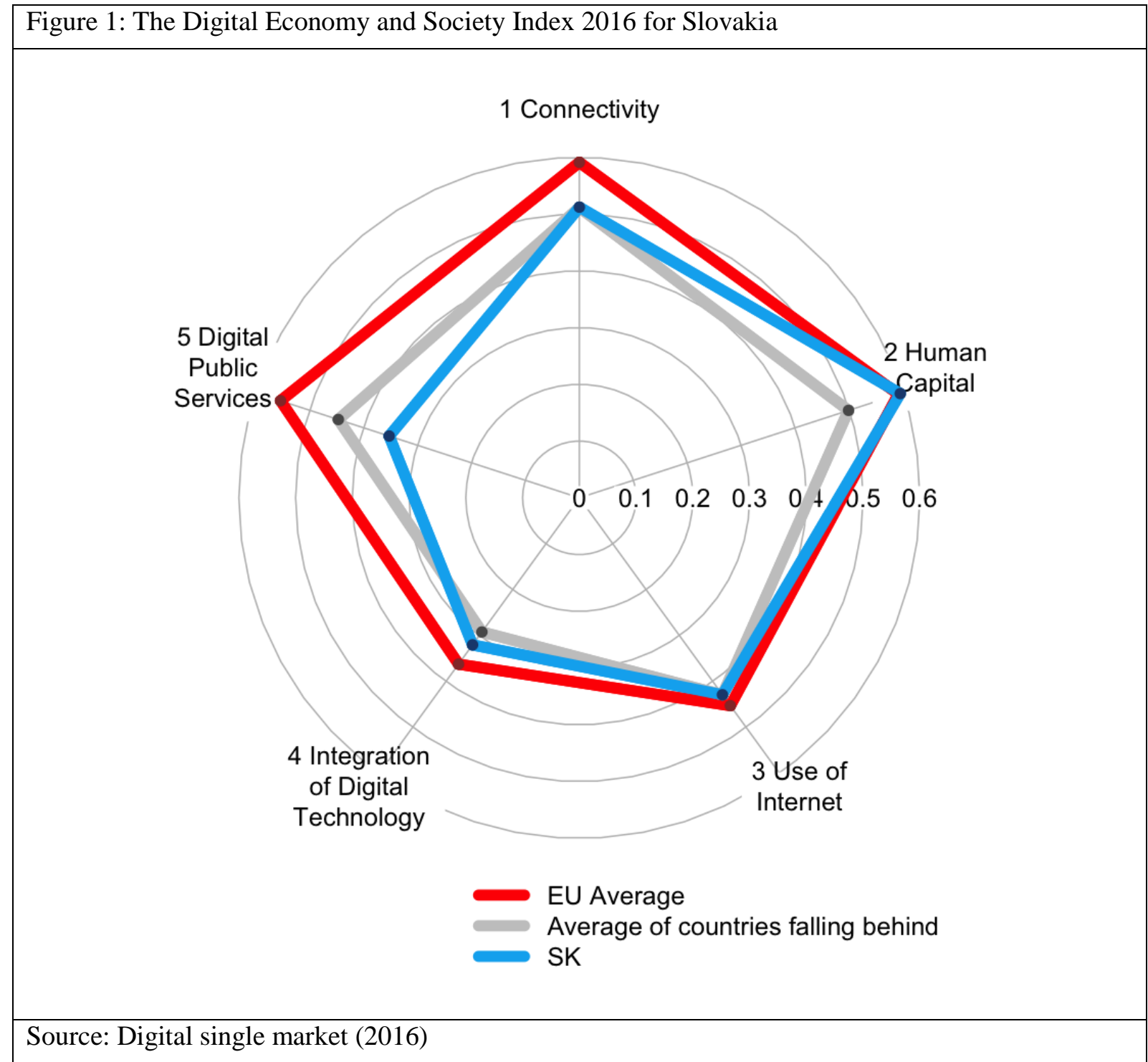


Figure 1 illustrates the results of the index DESI in 2016 for Slovakia compared to the EU average and the average of countries with 'falling behind' or 'lagging', where Slovakia was included in 2016.

\section{Necessity of Digital Integration of People with Disabilities}

The concept of integration in recent years is quite often used in connection with people with disabilities. This concept can be understood to mean a return or integration into society. The point of integration is, however, not only to equalize opportunities for the disabled, regularization of the 'majority' and 'minority', and cohabitation, but also the fruitfulness of including individuals with disabilities into society.

Currently, following the building of the information, as previously published by the author:

society is getting to the attention also the digital integration. Significant is the importance of ICT in access to information to citizens, to simplify their communication with the public administration and to increase the proportion of citizens in the management of the State. Ensuring access to information and information services for all citizens is one of the key requirements for the development of the information society. The availability of information and easy usability of the information electronic services and online services should avoid the emergence of two categories of citizens-those who have access to ICT and those who have not this access. The access to information is not enough, if the citizen has been not able to use ICT and information. Therefore, another key precondition for building the information society is to ensure the basic digital education, digital literacy for every citizen (Gregušová, Dulák, Chlipala, \& Susko, 2005).

In terms of building the information society can be seen as a digital integration and the issue of digital exclusion or e-inclusion of people with disabilities as key. In Slovakia, the situation is not satisfactory in this issue. In the light of the strategic objectives of the EU was received a document called the National Strategy for the Digital Integration of the Slovak Republic in the year 2008. The role of coordinator in this area had the Ministry of Finance of the Slovak Republic, which was the central government body in the field of informatization of society ten years. Currently from 1 July 2016 was established a new central government body - Deputy Prime Minister's Office for Investment and Informatization of the Slovak Republic. The establishment of an independent office for informatization is in line with international trends.

The possibilities of digital inclusion aiming to the greatest number of socially disadvantaged citizens and citizens at risk of digital exclusion are cumulated in the six basic areas: digital accessibility and usability of ICT, inclusive E-Government, digital literacy and raising the competence of the use of ICT, reducing geographical digital divide, promoting cultural diversity, ICT for the elderly

The key question appears to be the level of digital literacy of the people at risk of digital exclusion. Digital literacy and its development we can evaluated on the basis of the results of the research digital literacy in the Slovak Republic in the projects with the name of "Digital Literacy in Slovakia", which were realized in the years 2005-2015. The attention in this research was paid to the whole population and had not been specified only for people with disabilities. (Ondrejková, 2015, p. 205)

\section{E-Government Services and the Building of Integrated Service Points in Slovakia}

As previously stated by the author in Ondrejková, (2015):

An important aspect of digital integration is the use of the electronic services of public administration, E-Government services. E-Government is the electronic form of performance of the public administration with the application of ICT. Online communication works in the processes of public administration. The aim is to remove several repeated requests for information, documents and data businesses by the informatization of public administration. By the accelerated implementation of EGovernment services has streamlined processes in all areas where the interaction of the public administration to citizens or businesses. The new law on E-Government was in the Slovak Republic 
adopted in Act No. 305/2013 Coll. on electronic form the performance of public authorities, and on amendments to certain acts (the Act on E-Government) with effect from November 1, 2013.

Integrated service points represent a comfortable way to communicate with the authorities and institutions from a single location, and for professional help specifically trained personnel. The worker of this point, after carrying out the physical identification of the citizen, can make the electronic services of the public administration to the citizen, as if they were accessed directly by the citizen.

E-Services of the public administration will be available by this form also to citizens, who for various reasons cannot yet alone use the services of the public administration, namely the electronic services of E-Government. Serious reasons are for example the lack of technical equipment, such as outdated hardware and software, the unavailability of the Internet, the absence of the necessary technical skills and the necessary level of digital literacy, missing education in ICT. With such reasons and obstacles to use of electronic services of E-Government we can meet with the citizens of certain minority groups of our population, such as seniors, persons with disabilities, in the less-developed regions with high unemployment, citizens, and other socially disadvantaged groups (Integrated service point, 2016).

\section{New Directive on the Accessibility of Public Sector Bodies' Websites in the EU}

The following is from the web article, 'What is web accessibility?':

Web-accessibility means a website or web-based service (including those designed for mobile devices and/or use) which is easy to browse, navigate, understand, operate, interact with and use safely, securely, independently, and with dignity by a person with a disability under all circumstances (including emergency cases).

This does not exclude the use of assistive devices or augmentative and alternative communication to achieve accessibility for particular groups of persons with disabilities where this is needed (Moledo, 2016a).

In addition, the following is from the web article, 'Web accessibility: Why is it essential?'

In an increasing digitalized society, more and more essential information and services are available online. To access them, persons with disabilities and older people require websites designed according to web-accessibility standards to operate correctly with their assistive technologies. Unfortunately, most of the websites, including public websites, do not respect those standards and a vast majority of the population is excluded from using them (Moledo, 2016b). Then, there is, "In December 2012, the European Commission presented a proposal for a Directive on the accessibility of public sector bodies' websites" (Commission welcomes agreement to make public sector websites and apps more accessible, 2016).

In May 2016, the following was announced,

"Negotiators of the European Parliament, the Council and the Commission agreed on the first EUwide rules to make the websites and mobile apps of public sector bodies more accessible, especially for the blind, the deaf, and the hard of hearing.

The Internet has become an essential way to access and provide information and services. It is therefore more important than ever to make sure that everyone can perceive and understand websites and mobile apps, and interact with them properly"

Around 80 million people in the EU are affected by a disability. As the EU population ages, the figure is expected to increase to 120 million by 2020 . A common approach to ensure web accessibility will contribute to an inclusive digital society and to unlocking the benefits of the Digital Single Market, for all European citizens. 
The Directive will cover public sector bodies' websites and mobile apps, from administrations, courts and police departments to public hospitals, universities and libraries. It will make them accessible for all citizens - in particular for the blind, the hard of hearing, the deaf, and those with low vision and with functional disabilities (Commission welcomes agreement to make public sector websites and apps more accessible, 2016).

Along with the following:

Following political agreement (in 'trilogue', between negotiators of the European Parliament, the Council and the Commission), the text will have to be formally approved by the European Parliament and the Council. After that it will be published in the Official Journal and will officially enter into force. Member States will have 21 months to transpose the text into their national legislation (Commission welcomes agreement to make public sector websites and apps more accessible, 2016).

Web accessibility aims to improve access for disabled users to the information and functions available on the Internet. In order to offer the best search everyone, including people with disabilities, the site should be properly designed and developed. It must be emphasized that compliance with accessibility guidelines do not require any major investment but need to think about them in advance for creating web pages.

\section{Definition and Fundamental of Digital Literacy}

The following is from 'The implementation of digital technologies in education in kindergarten':

The need to define and specify the literacy arose together with evolution of society and the development of modern techniques. Under 'normal literacy' we are meaning the knowledge of reading and writing. Currently our society needs new literacy - the knowledge and skills in use of computers, multimedia, information and modern computer technology.

Information literacy is one of the fundamental aspects of civilizational literacy of contemporary man. It is based on demands of current society, entitled like information society. Information literacy thus includes knowledge, skills and understanding needed to adequate, safe and productive use of ICT in the learning process and knowledge, in employment and in everyday life. It becomes evident as the ability of effectively use information resources and informatics tools for the analysis, processing and communication of information and modeling, measurement, and management of external processes.

Digital literacy is essential part of information literacy. According to EuroActiv, the concept of "digital literacy" is the ability to understand the information and to use them in a variety of formats from a variety of sources that are presented through information and communication technology. According to Kalaš "digital literacy" is a set of knowledge, skills and understanding needed to adequate, safe and productive use of digital technology for learning and cognition - at work and in everyday life.

Computer literacy is part of digital literacy. The computer is the source of obtaining of information and communication. Computer literacy is a slave term and its competencies are part of the information literacy (Strýčková, 2014, pp. 209-210).

\section{The Research Project Digital literacy in Slovakia in the Years 2005-2015}

As previously stated by the author in Ondrejková, (2015): "This research project maps one of the key assumptions of successful transformation to an information society and the knowledge-based economy - readiness of the population to use modern ICT".

And further:

Digital literacy in general includes the ability to understand the information and to use them in a variety of formats via modern ICT and presented through different sources. The Institute for public 
affairs launched analytical-monitoring project in digital literacy named Digital literacy in Slovakia in the year 2005 .

The research project maps one of the key preconditions for successful transformation on the information society and knowledge-based economy - the readiness of the broad sections of the population to the use of modern ICT.

In addition to the standard mapping of the level of digital literacy of the population, in 2009, the project focused especially on disadvantaged social groups of the population - those who are illiterate or have low levels of this digital literacy and phenomenon the "digital divide" constitute in the society. (Ondrejková, 2015, p. 210)

The author then goes on to say in Ondrejková, (2015), the following:

Digital literacy constitutes quite a complex phenomenon, which, however, can effectively express through coefficient - index of digital literacy (Digital literacy index-DLI). This index includes the 27 indicators (questions) that measure the level of work with ICT and its applications and services.

Respondents in each of the questions reflect their skills and abilities on a scale of 1 - 'I manage it very well' to 5 'you do not manage it at all -'. The index value is placed on the point scale: from $0-1$ - the maximum level of digital literacy to illiteracy digital. Index of DLI included 28 indicators (questions) in the research in the year 2011.

The indicators are divided for convenience into four basic segments - control hardware, control software, information management and communication capability through ICT.

So far, the Institute implemented in the project Digital Literacy in Slovakia following studies:

2005 - Sample size: 1,345 respondents, field data collection: July - August 2005

2007 - Sample size: 1,149 respondents, field data collection: July - August 2007

2009 - Sample size: 1,134 respondents, field data collection: August 2009

2011 - Sample size: 1,138 respondents, field data collection: July 2011

2013 - Sample size: 1,079 respondents, field data collection: march 2013 (Velšic, 2013)

2015 - Sample size: 1,083 respondents, field data collection: April 2015 (Digital Literacy in Slovakia 2015, 2016)

The studies were representative of the whole population of Slovakia over 14 years in terms of gender, age, education, nationality, size cities and regions of Slovakia. Field data collection ensured on the basis of personal (face-to-face) interviews recorded in questionnaires FOCUS agency. The collected data were processed and analyzed by statistical methods.

Current share digitally literate population reached by data from a representative survey by the Institute for Public Affairs in March 2013, 79\% and digitally illiterate 21\% (Velšic, 2013).

A significant problem of the whole society in question is called digital literacy is digital divide or digital gap. Therefore, the allocation of the society for those who have access to ICT and the appropriate level of digital literacy, and those who have not such access or not literacy.

Different level of access to ICT, digital literacy and other parameters can be in the near future constitute an important factor of deepening social inequality. Particularly digital illiteracy in this context must be seen as a new driving force of poverty, because it reduces the chances for quality education, changes for well-paid employment, increasing qualifications and specialization, the assets and higher social status (Velšic, 2010). 
Institute for Public Affairs presented on July 7 in the year 2015 in Bratislava results of its long-term research project Digital Literacy in Slovakia, which takes place continuously since 2005. (p. 211)

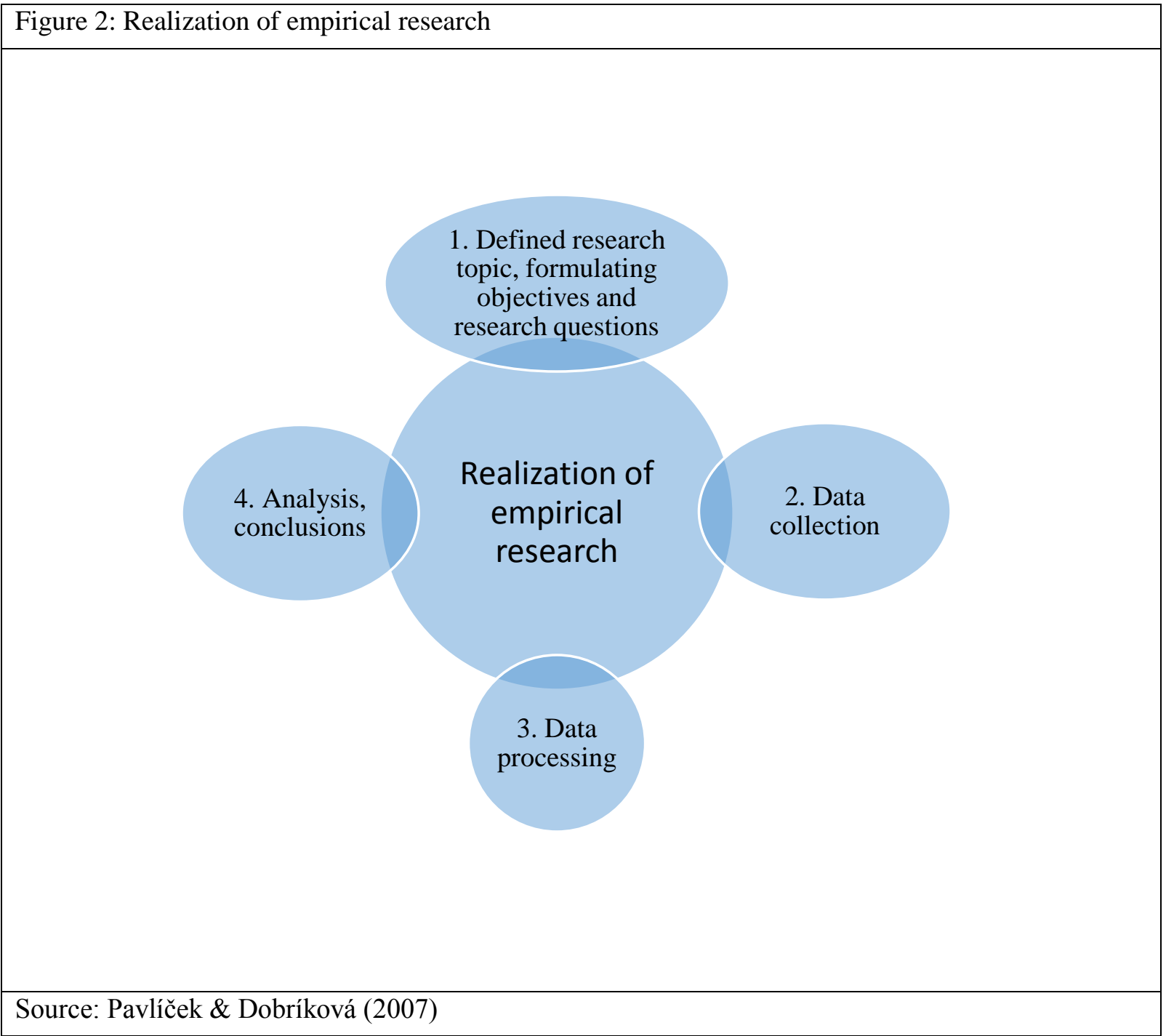

And following this the author goes on to say in Ondrejková (2015, p. 212):

The research in 2015 showed that a significant proportion of the population in Slovakia without key technologies such as computers, internet and mobile phones can no longer dispense. Without a mobile phone or smartphone could ever endure even one day to $36 \%$ of respondents, and without computers, notebooks, tablet or internet an additional $21 \%$.

Depending on modern ICT are the most vulnerable young people aged 14 to 34 years, students, higher education, business and intellectual workers. Various symptoms of dependence (e.g., When people forget to eat and drink, they are often a headache cannot sleep well or you do not manage to fulfill its obligations, etc.) Have noted for their relatives, acquaintances or friends and $35 \%$ of respondents. Most of them yet know in their vicinity more such cases.

Research findings further showed that the dependence of becoming a social concern, especially as documented increase in the intensity of use internet. While in 2013 it was used intensively, daily $31 \%$ at present it is already $49 \%$ of the population older than 14 years.

Institute for Public Affairs, through the project designers Marian Velsic so for a decade providing the comprehensive picture of the digital skills of the population in Slovakia for general public and professionals. The project presented adaptation to new trends in information technology and a reflection of social problems that IT generates (Digital Literacy in Slovakia 2015, 2016). 


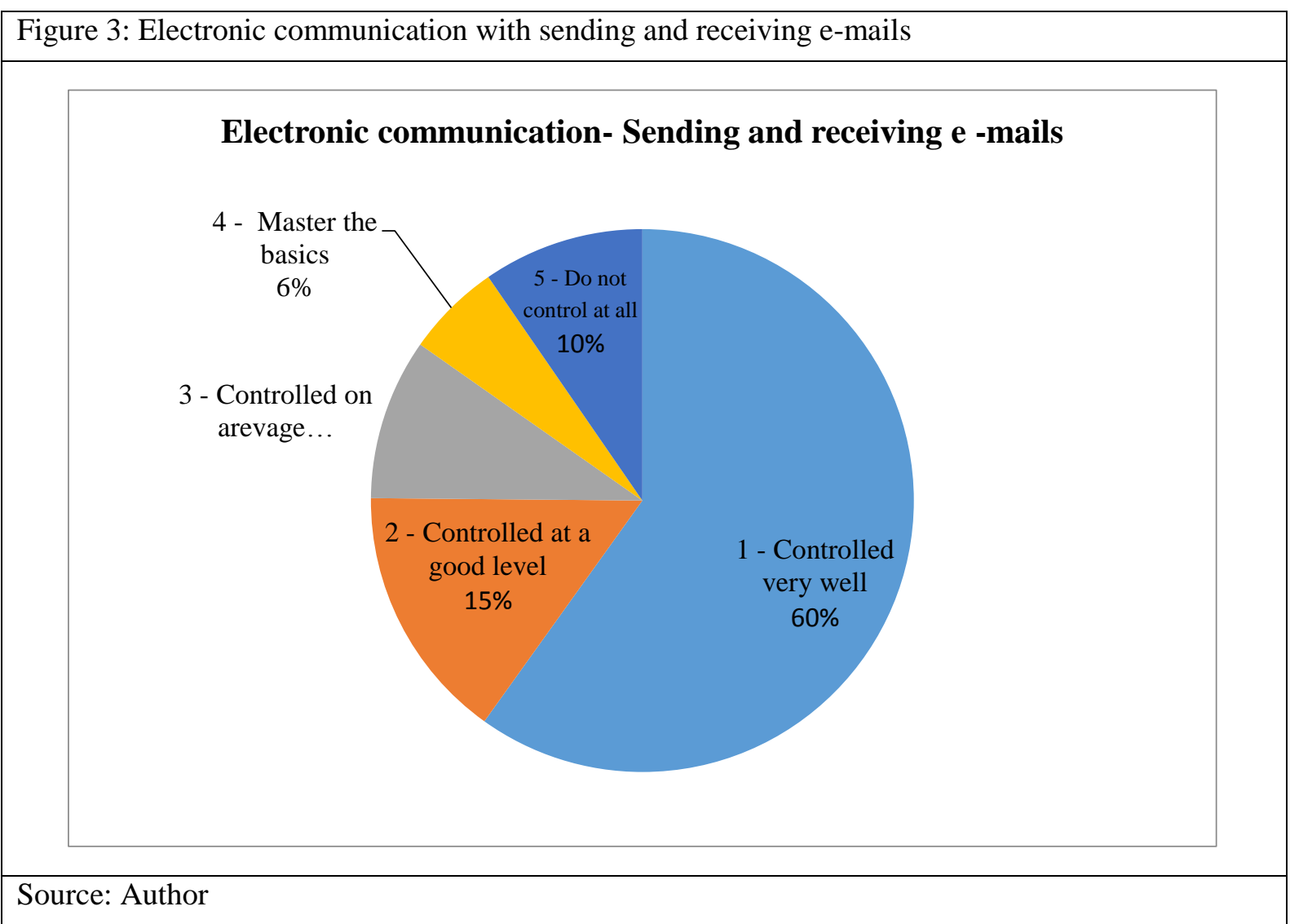

\section{Preparation and Implementation of Own Empirical Research}

The empirical data present great importance and weight in creating new knowledge in the social sciences and also in the natural sciences. Empirical research is research that is associated with the collection of facts in existence, with verification of theoretical assumptions through examination of real life, with the survey in the field. Quantitative research utilizes random selections, experiments, and strongly structured data collection from questionnaires, tests, or observations. The next step is to analyze the data obtained by statistical methods with the aim of verifying the truthfulness of our concepts, and where appropriate, describe them on the relationship of the variables. Correct identification of hypotheses, questions, and items will lead to the research goal, otherwise the objectives are not achieved.

At the beginning of empirical research, one identifies the topic and the problem. One identifies the purpose of research and determines the research questions or hypotheses. It is possible to complement research questions in the course of research, but the basic aim must be determined in advance. Next, one chooses the method in proposing a research plan to collect and analyze data and arrives at the conclusion and recommendations. One needs to use complex procedures allowing the system to build the required knowledge and verify the cognitive value in the process of scientific investigation.

Implementation of empirical research is illustrated in Figure 2.

\section{Using Excel for Statistical Data Processing}

In Microsoft Excel one can work with different tables. Some tables contain mainly figures with many formulas and functions to perform the required calculations. Another type of table in terms of data processing, in Excel are the registration type, where instead of calculating a review of storing large amounts of data (tens, thousands, tens of thousands) that enable the following dates refer briefly, conduct searches or of those data to extract valuable information (cumulative numbers, extreme, differences and dependencies). 
For this type of table, one uses the term database or later the list. On these tables can be applied to a number of tools to facilitate the creation and editing of spreadsheets and perform database operations such as searching, sorting, summary calculations and simple analysis with pivot tables.

These tables must be a habitually database structure. The column contains one type of data. The line contains one of the item (for example, one item of expenditure). The first line forms the header. Nowhere in the table are left out blank lines or columns. An important part of MS Excel are charts, which have better predictive value than the numerical table (Magera, 2007).

Special types of tables are the pivot tables, which one can create from other tables of database character. Pivot Tables are among the most popular tools of MS Excel. These provide insight into the processing of large amounts of data. In addition to conventional summaries (such as totals and averages) offer a range of different perspectives on the processed data, peer comparison data distribution in percentages, and running totals. The source data can be processed in a tabular and graphical form in a Pivot chart.

Pivot charts are used for graphical representation of data calculated in the Pivot Table. Compared to a standard graph are different:

- Pivot chart is not linked to a fixed range of cells, but with a pivot table whose size can change dynamically; and

- In a Pivot chart it is possible to use filtration as in pivot table (Laurenčík, 2014).

When one changes the source data one can update the pivot table and change is reflected immediately in Pivot Chart.

\section{The Research of Digital Literacy of People with Disabilities in Slovakia}

As previously published by the author in Ondrejková, (2015):

Within dissertation titled Information Technology - support the integration of persons with disabilities we realized social research on the minor part of the population of persons with disabilities in the field of digital literacy and the use of modern means of ICT. This is a quantitative type of research that the techniques of data collection for research uses questionnaire.

The inspiration for the creation of questions in the questionnaire was mapping digital literacy in the general population in Slovakia in representative research carried out by the Institute for Public Affairs in analytical and monitoring project Digital Literacy in Slovakia, which has been repeatedly effected in the years $2005-2015$.

The questions relate to four main areas: control hardware, control software, information management and services and the ability to communicate as well as specific issues relating to the use of special assistive technologies for certain groups of disabled people.

As technology for the development of the questionnaire we used Google questionnaires. All questions in the electronic questionnaire have been identified as mandatory, therefore it was necessary to choose one of the offered answers. Choice questions held by respondents simply click the mouse on an electronic questionnaire. Without answering all the questions, it could not be an electronic questionnaire to be sent for processing. The questionnaire was anonymous. The questionnaire asked 43 questions. The inlet section of questions, 11 questions, focused on classification of the respondent. As follows were questions concerning the digital literacy of people with disabilities.

The aim of the research is to evaluate the state of digital literacy among people with disabilities and evaluate the potential of ICT to promote the integration of disabled people into society.

The questionnaire survey is anonymous, respondents do not mention their names, surnames, addresses, personal identification number and so on. All collected data will be presented in aggregate form. The research results will be evaluated in terms of the potential of modern ICTs become promoting the integration of persons with disabilities into society here in Slovakia. 
After creating on-line electronic questionnaire, we addressed potential respondents. To promote research, completed questionnaires and get answers from the largest number of respondents we used mainly e-mail. We sent e-mails to e-mail addresses to the most organizations of persons with disabilities in Slovakia, we addressed representatives of schools for pupils with special needs and support centers for students with special needs and so on. We also personally visited several schools and organizations. The smaller part of the answers we received in form paper questionnaire, as it is foreseeable that especially older respondents are not sufficiently skilled in digital technologies.

Potential respondents, we addressed mainly through e-mail and cover letter. In the cover letter as well as in e-mails has been provided information, where there is an electronic on-line questionnaire and method of filling and electronic dispatch. Respondents were contacted via e-mail contact for many non-profit organizations of people with disabilities who are in Slovakia. Part of the email was also supplement with a cover letter in which we approached potential respondents approached purpose and significance of research and provide information about accessing and completing an electronic questionnaire. (p. 212)

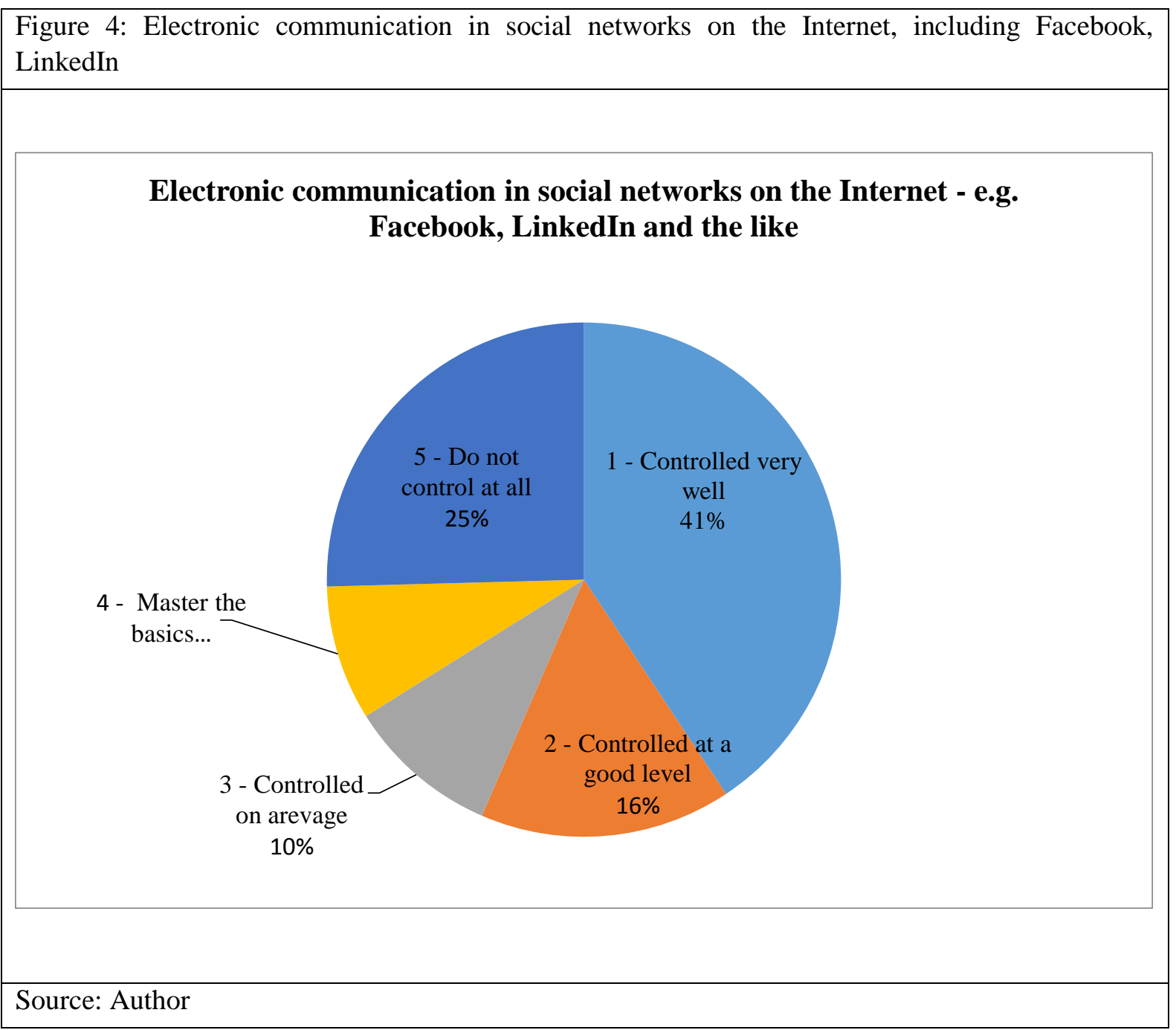

Data were collected between June 2014 and March 2015. The research involved 177 respondents. The data obtained through questionnaires was saved in file the format of Microsoft Excel 2013. The data were then analyzed using Pivot Tables and presented graphically with Pivot Charts.

Overall, we created more than 40 standard Pivot Charts to visualize data processing, with selected charts presented in Figures 4 and 6. 
We chose the area of the electronic communications, where people with disabilities have declared a very good level of digital skills. This area plays also very important role in daily life of the people with disabilities.

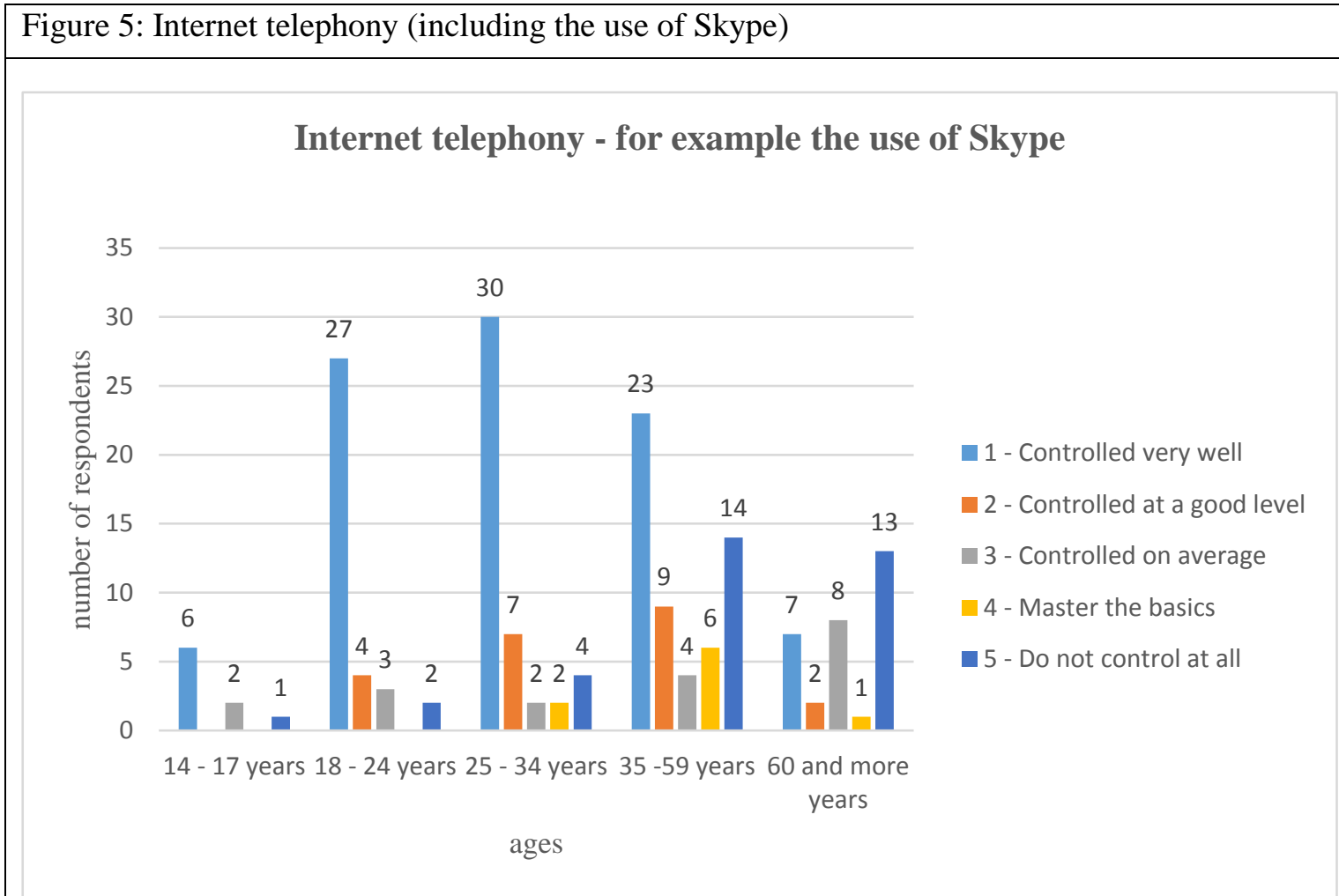

Source: Author

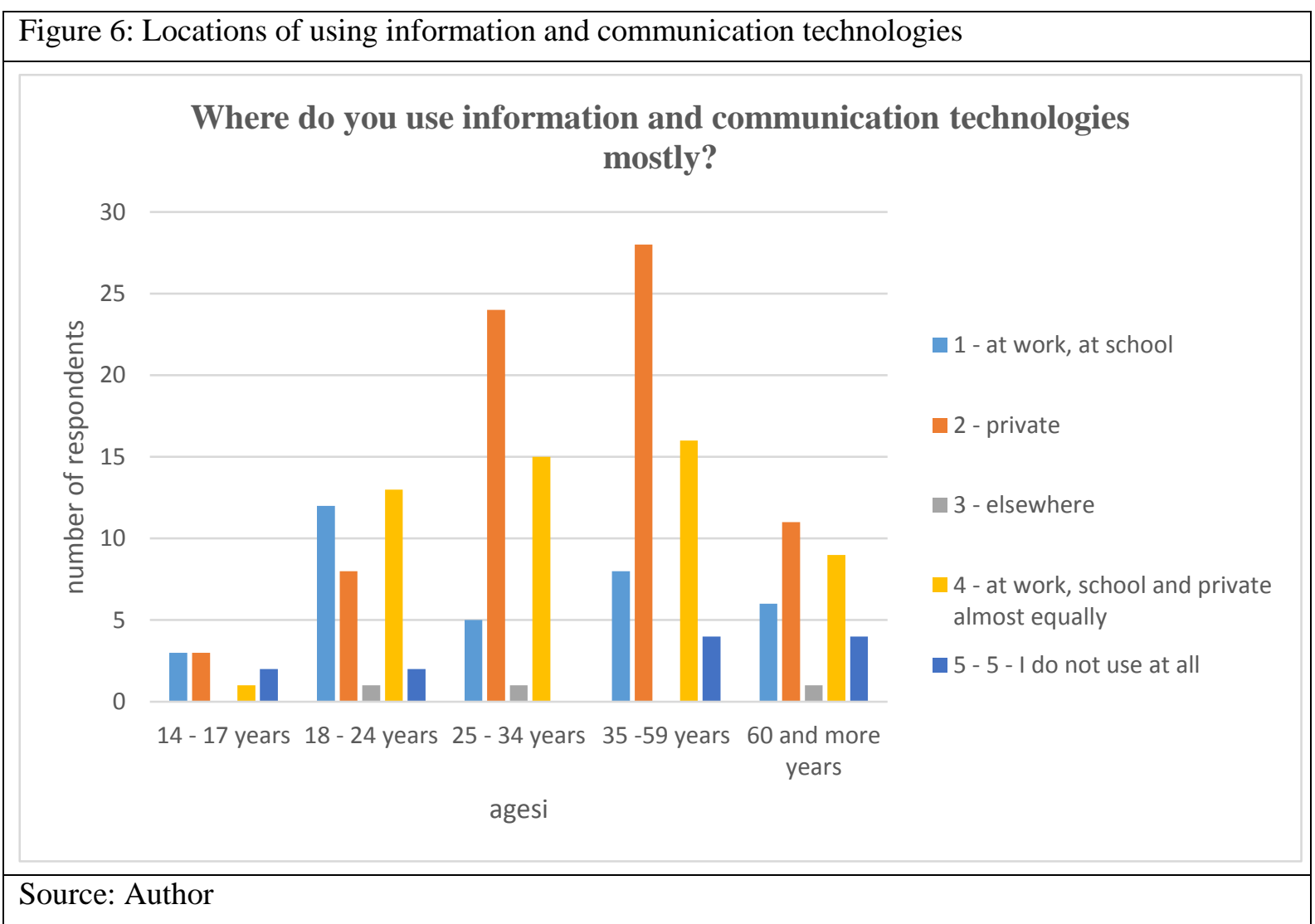




\section{Conclusion}

A key factor in today's society is the widespread use of ICT in all spheres of life. Internet as a global computer network is used daily by most of the population in searching for information, with electronic communication, electronic banking, electronic commerce, for pleasure during free time, and with the use of rich multimedia content. This implies the need for new competencies and skills for the $21 \mathrm{st}$ century. and therefore for digital skills and digital literacy. These competences are needed and desired in the performance of most professions, but also in private activities.

We highlighted in this article the evaluation of digital readiness of Slovakia under the new analytical tool, Digital Economy and Society Index (DESI). Slovakia was in 2016 ranked No. 21 among EU Member States. We are looking at a research project, Digital Literacy in Slovakia, which in the years 2005-2015 charted the development of digital literacy in Slovakia.

The role of the developed countries is also to ensure social and digital inclusion of people with disabilities into society. Therefore, we have highlighted the introduction of new E-Government services and the building of integrated service points in Slovakia and also the issue of web accessibility. In terms of the rules for web accessibility, it will play an important role in the future new Directive on the accessibility of public sector bodies' websites in EU. Member States of European Union will have 21 months to transpose the text into their national legislation after the adoption of directive.

People with disabilities cannot be digitally excluded, but they need to adapt to the information society. The level of ICT skills in people with disabilities in Slovakia, we have investigated through using a questionnaire in this research.

Respondents who participated in our research were in terms of disability divided as follows: 63 people with physical disabilities, 40 visually impaired people, and 20 people with multiple disabilities and other disabilities to a lesser extent.

Respondents who participated in our research were in terms of age divided as follows: 56 respondents aged $35-59$ years, 45 respondents aged $25-34$ years, 36 respondents aged $18-24$ years, and 31 respondents aged 60 and more years.

We chose the area of the electronic communications, where people with disabilities have declared a very good level of digital skills. This area plays also very important role in daily life of the people with disabilities and it is very popular not only for young generation.

\section{References}

Commission welcomes agreement to make public sector websites and apps more accessible (2016). Retrieved from http://europa.eu/rapid/press-release_IP-16-1654_en.htm

Digital single market (2016). Retrieved from https://ec.europa.eu/digital-single-market/en/scoreboard/slovakia

Digital Literacy in Slovakia (2015). Retrieved from http://www.ivo.sk/7739/sk/aktuality/digitalna-gramotnost-na-slovensku2015, 2016.

Europe 2020 strategy (2016). Retrieved from https://ec.europa.eu/digital-single-market/en/europe-2020-strategy

Gregušová, D., Dulak, A., Chlipala M., \& Susko, B. (2005). Právo informačných a komunikačných technológií [Law of Information and Communication Technology]. Slovenská technická univerzita v Bratislave [Slovak Technical University in Bratislava], ISBN 80-227-2195-6.

Integrated service point (2016). Retrieved from http://www.informatizacia.sk/integrovane-obsluzne-miesto---iom/13913s

Kelemen, J., Horáková, J., Berka, P., Bureš, V., Hvorecký, J. \& Mikulecký, P. (2007). Pozvanie do znalostnej spoločnosti [Introduction to the Knowledge Society] Bratislava: Iura Edition, 2007. p. 265.

Kosno, L. (2016). SR v digitálnych veciach pohorela, tvrdí analýza EÚ. Pozrite si dôvody [Slovak Republic lost castle in digital matters, says EU analysis: see statement]. Retrieved from http://www.zive.sk/clanok/112660/sr-v-digitalnych-veciachpohorela-tvrdi-analyza-eu-pozrite-si-dovody

Laurenčík, M. (2014). Excel 2013 práce s databázami a kontingenčními tabul'kami [Excel 2013 working with databases and Pivot Tables]. Grada Publishing, a. s. 176 p. 2014, ISBN 978-80-247-5003-3. 
Lipovská, A., Hvorecký, J. \& Šimúth, J. (2014). Virtuálna trieda, Sprievodca adaptívnym online vzdelávaním [Virtual class, The Guide of adaptive online learning]. Equilibria, s. r. o., 2014, 288 p. ISBN 978-80-8143-142-5.

Magera, I. (2007). Excel 2007 jednoduše [Excel 2007 simply]. Computer Press, a. s. Brno, 2007, 133 p. ISBN 978-80-2511694-4.

Moledo, A. (2016a). What is web accessibility? Retrieved from http://www.edf-feph.org/Page_Generale.asp?DocID=13855 \&thebloc $=34406$

Moledo, A. (2016b). Web accessibility: Why is it essential? Retrieved from http://www.edf-feph.org/Page_Generale.asp? DocID $=13854 \&$ thebloc $=28118$

Ondrejková, A. (2015). Digital literacy - a factor of integration and education of people with disabilities into society in the Slovak Republic in Proceedings of IAC-TLEl 2015 in Vienna: Czech Institute of Academic Education. Retrieved from https://books.google.com.au/books?id=eorjCgAAQBAJ\%D 2015

Pavlíček, J. \& Dobríková, P. (2007). Sociálny výskum a štatistické spracovanie dát [Social research and statistical data processing]. Vysoká škola zdravotníctva a sociálnej práce Sv. Alžbety [College of Health and Social Work Vol. Elizabeth], n. o. 2007, 83 p. ISBN 978-80-89271-16-0.

Strýčková, G. (2014). Implementácia digitálnych technológií do edukácie v materskej škole [The implementation of digital technologies in education in kindergarten]. Metodicko - pedagogické centrum [Methodological - pedagogical center] 2014, ISBN 978-80-8052-774-7.

Šimkovič, J. (2016). EÚ v digitálnej oblasti napreduje pomalšie, než by chcela [The EU is progressing more slowly in the digital area than it would like]. Retrieved from http://euractiv.sk/informacna-spolocnost/eu-v-digitalnej-oblasti-napredujepomalsie-nez-chcela

Velšic, M. (2010). Interaktívna mapa digitálnej [ne]gramotnosti [Interactive map of Digital Literacy]. Retrieved from http://www.ivo.sk/5869/sk/vyskum/interaktivna-mapa-digitalnej-[ne]gramotnosti

Velšic, M. (2013). Digitálna gramotnost' na Slovensku 2013, Správa z výskumu [Digital Literacy in Slovakia 2013, Research report]. Inštitút pre verejné otázky, Bratislava [Institute for Public Affairs, Bratislava]. 15 p. ISBN 978-80-89345-40-3.

What is the digital readiness of Slovakia? (2016). Retrieved from: https://europskenoviny.sk/2016/02/26/aka-je-digitalnapripravenost-slovenska/ 